\title{
Existence Of Criminal Fine In Criminal Act Of Corruption
}

\author{
Nurhilmiyah1, Ida Hanifah2, Asliani \\ Department of Law UMSU, Indonesia1, Department of Law UMSU, \\ Indonesia2, Department of Law UMSU, Indonesia \\ nurhilmiyah@umsu.ac.id1,idahanifah@umsu.ac.id2, \\ asliani@umsu.ac.id3
}

\begin{abstract}
Criminal fines have become a phenomenon and a long result about the partnership system in Indonesia. Criminal fines are no longer carried out properly and can be accepted in the eyes of the law because fines can be carried out or cannot. Today in Indonesia, a fine criminal has become a phenomenon and a long debate about the imaging systems in Indonesia. This research uses normative and empirical legal research methods. Conducted at the Medan District Prosecutor's Office and the Corruption Court of the Medan District Court, by collecting legal materials related to imposing fines on the Corruption Court. The data obtained is then processed and analyzed with those obtained from the findings that are expected to be obtained from the new policy in criminal law. The results of this study, the existence of imprisonment in eradicating corruption does indeed exist in our law enforcement. It's just that considering it is not significant enough to help achieve one of the goals of punishment is to recover state finances. Several factors related to the substance of the law greatly affect the existence of a court based on this, one of which has nothing to do with the law concerning boundaries.
\end{abstract}

Keywords: existence, criminal penalties, criminal acts of corruption.

\section{Introduction}

Behavior that does not match the norm or can be referred to as misappropriation of the agreed norms turned out to cause disruption of the order and tranquility of human life. The irregularities that are so usually by the community are labeled as transgression and even as a crime. Evil in human life is a social symptom that will always be faced by every human, community and even state. Reality has proved that crime can only be prevented and reduced but difficult to eradicate completely. 
Criminal rationing is not merely a retaliation, the most important is the giving of guidance and Pengayoman. The Pengayoman at the same time to the public and bankruptcy itself to become converted and can be a good member of society. Such a new conception of the pipetting function is no longer a mere depenation, but also as a rehabilitation and social reintegration effort. The conception in Indonesia is called correctional.

Criminal is the most fundamental component in the study of criminal law. Not even excessive if it is stated that criminal law without criminal, is not criminal law. It is necessary to affirm that despite criminal acts and criminal liability, it means that there is no "criminal" which is why it is called a criminal law as a special sanction law.

According to Sudarto, the history of criminal law is in fact a history of criminal and Pemidanaan. Criminal is also an action (Maatregal) that raises a suffering, something that is felt not tasty by being charged. Therefore people ceaselessly to seek the basis, nature and purpose of criminal and pipetting, to provide the reason for the criminal justification.

In criminal and pipetting systems, Indonesian criminal law has set about sanctions against criminal acts as referred to in article 10 letter a digit (4) e KUHP i.e. criminal fines. Where fines for criminal penalties applied are the principal penalties in the EAS system in Indonesia. A penalty is a means of payment to a state that is granted to a criminal who violates the provisions of the Law and the laws governing in a particular country.

Today in Indonesia, a fine criminal has become a phenomenon and a long debate about the imaging systems in Indonesia. Where fines are no longer executed and are recognized and acknowledged to be the legal subject of a criminal penalty can be executed or could not, in this case there are alternatives that can be taken by criminal such as selecting a subsidiary sentence with The addition of sentenced to prison verdict imposed by the tribunal of judges. The debate is one of the problems eradicating corruption crimes that better prioritize criminal fines. The goal of fines applied to criminal corruption is to cover the losses of countries that have been intercepted or abused by the corruptors as well as an attempt to eradicate corruption.

Corruption crimes became the public spotlight both nationally and internationally which became the main target of the criminal system fine is to add a deterrent effect to the makers or perpetrators of the criminal. Corruption crimes 
occurred in every central and local government as in North Sumatra many criminal acts of corruption that have detrimental to the state finances occur. One of the matters handling corruption in North Sumatra is in the court of the District Court of Medan as a central court in every region of North Sumatera.

It is currently not known that the application of fine penalties implemented in the Court is effective or not on this issue. This is where in-depth research is held in order for the implementation of the judicial institutions to be executed in accordance with the objective of the positive law in applying penalties in accordance with the methods of criminal law in Indonesia.

\subsection{Signifcance of the study}

The specific purpose of this research is to produce findings that are expected to encourage new policies of criminal prosecution in criminal acts of corruption.

Criminal fines become prolonged polemic because they are related to the imaging systems in Indonesia. Fines are no longer executed and are recognized as being in the eyes of the law, because fines in practice can be applied or could not, in this case there are alternatives that can be taken by criminal such as selecting a subsidation sentence with The addition of the sentence of confinement of the prison verdict dropped by the tribunal. Penalties are particularly in the case of corruption crimes as a goal to create a deterrent effect to the corruption perpetrators in order not to repeat the same crimes.

\subsection{Scope and Limitation of the study}

Due to time and financial constraints, study recognizes many limitations not only in terms of its scope and focus but also in its time frame, and others. On its scope and time-frame, it focused only on existence of criminal fine in criminal act of corruption at Medan Distric Court, 2017-2018.

\subsection{Setting of the study}

The study was conducted in two institutions, Medan District Court and Medan District Prosecutors Office during three months. 


\section{Research Design And Methodology}

In general, this study employed a descriptive research design which made us of both the primary as well as the secondary data. In trying to look for existence of criminal fine in criminal act corruption. The second type of data was gathered from written materials available in the different institutions in Medan as well as those found on-line. Moreover, content analysis was used to interpret the existence of criminal fine in criminal act of corruption.

\subsection{Research Instrument}

In gathering the primary data, the only instrument used in this research was structures questionnaire. It consisted on two parts. Part 1 to the judge and Part 2 to the prosecutor.

\subsection{Data Gathering Procedure}

First, the researchers sent a letter addressed to the Medan District Court through the register asking approval to get court ruling that related to corruption. Second, the researchers conducted administered the pretesting of the questionnaire for validation of the said instrument. Third is the sampling and actual identification by the researchers of the actual respondents. Questionnaires were retrieved right away after the respondents have answered them all.

Based on the annual data recapitulation section of the District Court Bank of Medan. The number of the cases entered in the year

2017 of 129 matters. Plus the remainder of the year 2016 to 185 matters. The number of corruption that were disconnected in 2017 amounted to 134 cases with details, the case of 2016 as many as 56 cases, and the matter of 2017 alone as much as 78 files. 
The time of the corruption in 2017 was 51 and the matter entered in 2018 a number of 128 cases. Total was 179 things in the year 2018. Then the 138 thing was disconnected, the remainder of the year 2018 as many as 41 cases. Based on an interview with the courts of Medan District Court as publicist, Mr. Jamaluddin, SH., MH, most of the cases that were disconnected at the Medan District Court, did not implement a penalty imposed by judges. In practice, a convicted corruption took an alternative to a subsidiary sentence with the addition of a confinement sentence of a prison verdict dropped by the Assembly of judges. To get more research results we went to the research site of another one that is the Medan prosecutor's office. The interview was conducted with prosecutor Tipikor in this regard as the Pidsus Kasi of the Medan attorney, Mr. Sofyan Hadi, SH., MH. Data obtained, in the year 2017 the case of a convicted of 18 cases, with details that pay a penalty of only 9 cases. Meanwhile, in 2018 the number of cases sentenced to 26 cases. With a breakdown of only 19 things that carry out fines.

In terms of percentages it can be calculated that pays a fine of about $40 \%$ of the total number of convicted cases. Whereas in accordance with article 10 of the criminal CODE that reads, criminal consists of criminal treesdeath, imprisonment, confinement, and fines-and additional criminal-the revocation of certain rights, and the announcement of the decision of the judge. Penalties are categorized as criminal penal CODE.

Based on an interview with Kasi Pidsus, in the last two years there has been an increase in the number of convicted parole (PB). This is what causes the implementation of fines. Regarding $\mathrm{PB}$, referring to the regulation of the Minister of Law and Human Rights of the Republic of Indonesia No. 3 of 2018 on terms and procedures of granting remission, assimilation, family visiting leave, conditional liberation, free-to-go leave, and conditional leave, Section 82 of the terms and ordinances of granting parole. The conditional liberation of Create is given to a qualified convict:

a. has been serving the shortest criminal period of $2 / 3$ (two-thirds), with the provisions of $2 / 3$ (two-thirds) of the criminal period at least 9 (nine) months.

b. Conduct either during the last 9 (nine) months of criminal period, calculated before the date of $2 / 3$ (two-thirds) of the criminal period. 
c. Have followed the coaching program well, diligently and enthusiastically, and

d. The community can receive prisoners ' coaching activities program.

So for the convicted crime that proposed a PB, the convicted criminal is obliged to undergo an alternative sentence of confinement sentence of 6 (six) months of the Subsidair. As for the convicted who did not apply for the NT, they did not carry out fines, simply settle the substitute money according to the country's financial loss value. It is quite dilemma because if calculated the amount of financial losses of the country or the country's economy is not comparable to the length of the convicted man undergoes criminal plus costs incurred in the handling of the procedure itself, including The costs incurred by the correctional institution during the criminal period.

Ideally it is convicted of paying fines, in addition to containing a deterrent effect, if the nominally can be maximised can recover the financial losses of the country or state economy. In fact, the greater the amount of fines being dropped, the more minimal amount of the convicted. They prefer to undergo a confinement sentence.

Medan District attorney and prosecutors in general in this case focus on prosecution for the issue of the Big Fish in order to balance the value of corruption with the costs incurred by the State for a one-time handling of the case of corruption. There is a legal norm governing the limits of fines.

The absence of the rules on this limitation of fines also complicates law enforcement in this case prosecutors and judges in carrying out its duties. It is also the legal norm regarding the punishment of confinement. There have been no rules regarding the addition of criminal confinement. Article 30 of the criminal CODE only mentions that a fine criminal is at least two hundred and fifty rupiah and if the fine is not paid then it is replaced by criminal confinement (called a criminal confinement replacement fine) at least 1 (one) day and Forever 6 (six) months.

This gap is used by the convicted corruption to prefer the criminal confinement which is only six months from paying a fine such as Rp. 50 million,-(fifty million rupiah). If the problem of this arrangement is not due to the way out, the predictability of the concern in the country is still difficult to eradicate because its legal substance needs to be addressed. 


\section{Findings and Conclusion}

The existence of criminal fines in eradicating criminal acts of corruption does exist in our law enforcement. It's just that its existence is not significant enough to help achieve one of the goals of punishment is to restore the country's financial or economic situation. Several factors related to the substance of the law greatly affect the existence of the criminal fines, one of which is the absence of legal rules regarding the limitation of fines and the addition of imprisonment.

\section{Recommendations}

New legal norms need to be made regarding the limitation of fines and the addition of imprisonment.

\section{References}

Adami Chazawi I. 2002. Criminal Law Lessons Part I (Criminal Structures, Criminal Acts, Criminal Theories \& Limits of the Applicability of Criminal Law). Jakarta: Rajawali Press, p. 12.

Bambang Waluyo. 2000. Criminal and Criminal. Jakarta: Sinar Grafika, p. 43

Chairul Huda. 2006. From No Criminal Without Error Towards No Criminal Accountability Without Error. Jakarta: Kencana, p. 26-27.

Djamali Abdul. 1999. Indonesian Law Enthusiasts. New edition. Jakarta: PT. Raja Grafindo Persada, p. 87.

Djoko Prakoso. 1990. The Role of Oversight in Deterrence of Corruption Crimes. Jakarta: Aksara Persada Indonesia, p. 78

Evi Hartanti. 2012 Corruption Crime (Second Edition). Jakarta: Sinar Grafika, 37.

Leden Marpaung I. 1992. Corruption (Problems and Solutions). Jakarta: Sinar Grafika, p. 13. 
Mohammad Taufik Makarao, 2005. Renewal of Indonesian Criminal Law (Study of Criminal Forms in particular Whip Crimes as a Form of Criminal Justice) Yogyakarta: Discourse Creation, p.11.

M. Hamdan, 1996. Criminal Law Politics. Jakarta: PT. Raja Grafindo Persada, 90. Niniek Suparni. 2007. Existence of Criminal Systems in Criminal and Criminal. Jakarta: Sinar Grafika, 22.

Waluyadi. 2003. Indonesian Criminal Law. Jakarta: Djambatan, 35.

Criminal Code (KUHP)'

Criminal Procedure Act (KUHAP)'

Law No. 31 of 1999 concerning Eradication of Corruption Crimes

Law No. 20 of 2001 concerning Eradication of Corruption Crimes

"Efforts to Eradicate Corruption" via http // Wasis-Priyatno.blogspot.com / 2011/04 / efforts to eradicate corruption, activate it on September 28, 2019 at 21:00 WIB 